\section{Der Lebkuchenkongress hat für 2017 eine neue Heimat gefunden!}

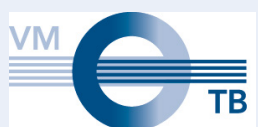

Am 15. und 16. Dezember 2017 wird der „Fortbildungskongress für Assistenzpersonal in der Radiologie, Nuklearmedizin und Strahlentherapie " in der Meistersingerhalle in Nürnberg stattfinden. Wir freuen uns sehr, Sie dort in der Adventszeit des Jahres 2017 begrüßen zu dürfen. Ihre VMTB

Impressionen von der Meistersingerhalle: Fotograf: Christian Höhn; copyright: Meistersingerhalle
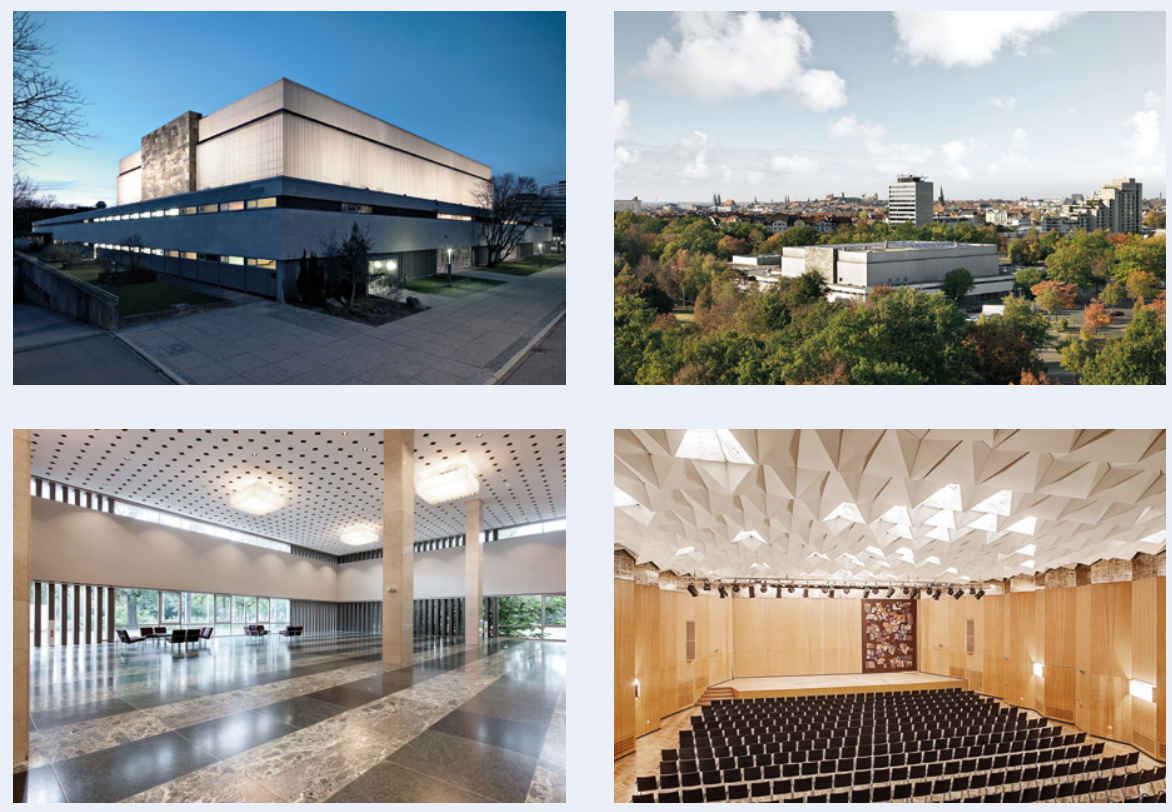